\title{
An analysis of some basic chemical and physical properties of drained fen peat and moorsh soil layers
}

\author{
MILENA TRUBA ${ }^{1}$, RYSZARD OLESZCZUK ${ }^{2}$ \\ ${ }^{1}$ Department of Grassland and Landscape Architecture, University of Natural Sciences and Humanities \\ in Siedlce \\ ${ }^{2}$ Department of Environmental Improvement, Warsaw University of Life Sciences - SGGW
}

\begin{abstract}
The analysis of some basic chemical and physical properties of drained fen peat and moorsh soil layers. The paper presents the results of measurements of some chemical properties for 14 drained fen peat-moorsh layers taken from north-east, central and east part of Poland. These areas were drained in order to use as a grassland and most of them in former time were under sub-irrigation systems. The following basic chemical properties were analysed: organic $\mathrm{C}$, total $\mathrm{N}$, $\mathrm{C}: \mathrm{N}$ ratio, $\mathrm{pH}$ and ash content. In the paper also the relationships between some basic chemical and physical properties were analysed (ash content with bulk density, particle density and porosity). Increasing of ash content caused the decreasing of some chemical properties (organic carbon and total nitrogen content) and increasing some physical properties (bulk density and particle density).
\end{abstract}

Key words: peat, drainage, humification, mineralisation, changes of chemical and physical properties

\section{INTRODUCTION}

The drainage of organic soils in order to agricultural, forest or horticulture use causes many physical, chemical and biological changes. Drainage and intensive use of peatlands are the main factors causing the moorshing process, which transforms peat in the surface layers into a new material called moorsh. The lowering of groundwater level and moisture content starts many irreversible physical processes like surface subsidence, shrinkage, changing of basic physical properties - increasing of bulk density, particle density and decreasing of porosity and saturated moisture content (Zawadzki and Olszta 1989; Okruszko 1993; Zeitz and Velty 2002; Oleszczuk et al. 2003; Peng and Horn 2007; Gebhart et al. 2009). Also the hydraulic and retention properties like saturated and unsaturated hydraulic conductivity and retention characteristic ( $\mathrm{pF}$-curves) shown after drainage of the organic matter the decreasing of water retention and hydraulic ability of peat soils (Oleszczuk et al. 2000; Gnatowski et al. 2002; Brandyk et al. 2003; Gnatowski 2009; Gnatowski et al. 2009).

Also the chemical changes in drainage peat soils due to increasing of air content in soil matter are observed: humification and mineralisation. Due to drainage process some part of organic carbon as a $\mathrm{CO}_{2}$ is emitted to the atmosphere and some part of $\mathrm{CO}_{2}$ is dissolved in groundwater (Clark et al. 2011). It depends on 
many factors: the depth of drainage, temperature of soil, $\mathrm{pH}$, fertilisation and type of land use (Ilnicki and Iwaszyniec 2002; Oleszczuk et al. 2008; Kechavarzi et al. 2010).

Due to nitrification processes nitrous oxide is also emitted to the atmosphere and some nitrogen compounds are accumulated in the top peat layers during moorshing process in comparison with natural non-drained peat soils (Okruszko 1993; Gotkiewicz 2007). According to Gotkiewicz (2007), total nitrogen for fen peatlands varies between $2.5-3.5 \%$, while for the raised bogs it is $0.5-1.0 \%$. In contrast, according to Maciak and Liwski (1996), total nitrogen for fen peatlands is $2-4 \%$ and for raised bogs is $0.8-1.2 \%$. The decreasing of organic carbon content and increasing of nitrogen in the top layers of drained peat-moorsh soils is often described as $\mathrm{C}: \mathrm{N}$ ratio. In case of natural peat deposits this ratio is quite wide (1:20) but in drained and strong decomposed peat and moorsh layer this relatioship is very narrow $(1: 12)$. According to Gotkiewicz (2007), C:N ratio for the fen peatlands is in the range 10-20 and for the raised bogs is 50-60.

Natural (no drained) fen peatlands are characterized by low ash content (1-5\%), strong decomposition of organic matter causes the increasing the ash content (Okruszko 1971; Okruszko 1993).

Presented physical and specially chemical processes (mineralization) are main reason, that a long time after drainage the surface subsidence and peat thickness deposit is still decreasing. Average surface subsidence for peat deposits under grass utilisation is around 1-2 cm per year (Wösten et al. 1997; Jurczuk 2011; Querner et al. 2012).
The aim of this study is to analyse some basic chemical properties of drained peat-moorsh soils representing soil layers for drained lowland fen peatlands (alder, sedge, reed and moss) and moorsh under sub-irrigation systems and comparison of some obtained data with results published in the literature.

\section{MATERIALS AND METHODS}

The analysed peat-moorsh soil layers taken into account in this study are located in three following sites in Poland: north-east part of Biebrza river valley, central part - Mazovia and east part - Lubelskie upland. All of these peatlands are lowland fen and they were drainaged in $20^{\text {th }}$ century and used usually as grassland or meadows. Some of them are still used by agriculture and some of them are abandoned areas. The undisturbed soil samples were taken in four replications from each of characteristics soil layers in analysed 9 soil profiles. The localisation, name of sites depth of sampling and peat classification (Systematyka gleb Polski 2011) are presented in Table 1.

The measurements of organic carbon were performed using TOC 5000A apparatus. This method based on measurements of carbon dioxide emission during burning of organic matter in temperature $680^{\circ} \mathrm{C}$ (Namieśnik et al. 2000). Some controlling measurements of organic carbon content were done using wet oxygen method (Maciak and Liwski 1996). The obtained results using this two methods shown very similar values. The total nitrogen in analysed soil samples was determined using Kjeldehal method, $\mathrm{pH}$ in destilled water (Sapek and Sapek 1997). The ash content values 
TABLE 1. Localisation and type of analysed peat-moorsh soil layers

\begin{tabular}{|c|c|c|c|c|c|c|}
\hline No & Community / Voivodeship & $\begin{array}{c}\text { GPS } \\
\text { position }\end{array}$ & $\begin{array}{l}\text { Name of } \\
\text { site }\end{array}$ & $\begin{array}{c}\text { Depth } \\
\text { of sampling } \\
{[\mathrm{cm}]}\end{array}$ & $\begin{array}{l}\text { Peat } \\
\text { group }\end{array}$ & Type \\
\hline 1 & Rajgród / Podlaskie & $\begin{array}{l}\mathrm{N}: 53^{\circ} 40^{\prime} \\
\mathrm{E}: 22^{\circ} 39.37^{\prime} \\
\end{array}$ & Bełda & $30-40$ & \multirow{2}{*}{ Alder } & $\begin{array}{l}\text { Hemic } \\
\text { (OTe) }\end{array}$ \\
\hline 2 & Góra Kalwaria / Mazowieckie & $\begin{array}{l}\mathrm{N}: 52^{\circ} 2^{\prime} 19.4^{\prime \prime} \\
\mathrm{E}: 21^{\circ} 6 \\
6\end{array}$ & Solec & $35-45$ & & $\begin{array}{l}\text { Hemic } \\
\text { (OTe) }\end{array}$ \\
\hline 3 & Rajgród / Podlaskie & $\begin{array}{l}\mathrm{N}: 53^{\circ} 40^{\prime} 13.2^{\prime \prime} \\
\mathrm{E}: 22^{\circ} 34^{\prime} 31.7\end{array}$ & Miecze & $50-60$ & \multirow{3}{*}{ Reed } & $\begin{array}{l}\text { Fibric } \\
\text { (OTi) }\end{array}$ \\
\hline 4 & Rajgród / Podlaskie & $\begin{array}{l}\mathrm{N}: 53^{\circ} 36^{\prime} \\
\mathrm{E}: 22^{\circ} 36^{\prime} \\
32.7^{\prime \prime}\end{array}$ & Sołki & $50-60$ & & $\begin{array}{r}\text { Hemic } \\
(\mathrm{OTe})\end{array}$ \\
\hline 5 & Skórzec / Mazowieckie & 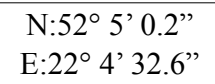 & $\begin{array}{c}\text { Dąbrówka } \\
\text { Stany } 1\end{array}$ & $60-70$ & & $\begin{array}{l}\text { Sapric } \\
\text { (OTa) }\end{array}$ \\
\hline 6 & Warszawa / Mazowieckie & $\begin{array}{l}\mathrm{N}: 52^{\circ} 7^{\prime} \\
\mathrm{E}: 21.1^{\circ} 6^{\prime} \\
\end{array}$ & Powsin & $30-45$ & \multirow{5}{*}{ Sedge } & $\begin{array}{l}\text { Hemic } \\
\text { (OTe) }\end{array}$ \\
\hline 7 & Warszawa / mazowieckie & $\begin{array}{l}\mathrm{N}: 52^{\circ} 7 \\
\mathrm{E}: 21^{\circ} 6 \\
6\end{array}$ & Powsin & $45-55$ & & $\begin{array}{l}\text { Hemic } \\
\text { (OTe) }\end{array}$ \\
\hline 8 & Serniki / Lubelskie & $\begin{array}{l}\mathrm{N}: 51^{\circ} 26^{\prime} \\
\mathrm{E}: 22^{\circ} 48^{\prime} \\
\end{array}$ & Brzostówka & $45-55$ & & $\begin{array}{l}\text { Hemic } \\
\text { (OTe) }\end{array}$ \\
\hline 9 & Skórzec / Mazowieckie & $\begin{array}{l}\mathrm{N}: 52^{\circ} 4^{\prime} 48.0^{\prime \prime} \\
\mathrm{E}: 22^{\circ} 5^{\prime} 11.8^{\prime \prime}\end{array}$ & $\begin{array}{c}\text { Dąbrówka } \\
\text { Stany } 2\end{array}$ & $45-55$ & & $\begin{array}{c}\text { Hemic } \\
(\mathrm{OTe})\end{array}$ \\
\hline 10 & Skórzec / Mazowieckie & 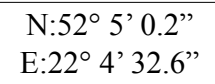 & $\begin{array}{l}\text { Dąbrówka } \\
\text { Stany } 1\end{array}$ & $45-55$ & & $\begin{array}{l}\text { Sapric } \\
\text { (OTa) }\end{array}$ \\
\hline 11 & Grajewo / Podlaskie & $\begin{array}{l}\mathrm{N}: 53^{\circ} 37^{\prime} \\
\mathrm{E}: 22^{\circ} 34^{\prime} \\
56.1 " 1\end{array}$ & $\begin{array}{l}\text { Lamane } \\
\text { Grądy }\end{array}$ & $50-60$ & Moss & $\begin{array}{l}\text { Fibric } \\
\text { (OTi) }\end{array}$ \\
\hline 12 & Serniki / Lubelskie & $\begin{array}{l}\mathrm{N}: 51^{\circ} 26^{\prime} \\
\mathrm{E}: 24.2^{\circ} \\
\end{array}$ & Brzostówka & $15-25$ & \multirow{3}{*}{ Moorsh } & - \\
\hline 13 & Skórzec / Mazowieckie & $\begin{array}{l}\mathrm{N}: 52^{\circ} 4^{\prime} 48.0^{\prime \prime} \\
\mathrm{E}: 22^{\circ} 5^{\prime} 11.8^{\prime \prime}\end{array}$ & $\begin{array}{c}\text { Dąbrówka } \\
\text { Stany } 2\end{array}$ & $20-30$ & & - \\
\hline 14 & Góra Kalwaria / Mazowieckie & $\begin{array}{l}\mathrm{N}: 52^{\circ} 2^{\prime} 19.4^{\prime \prime} \\
\mathrm{E}: 21^{\circ} 6 \\
6\end{array}$ & Solec & $10-20$ & & - \\
\hline
\end{tabular}

for each soil layer was determine by igniting dry soil samples in a muffle furnace at about $550^{\circ} \mathrm{C}$ until constant weight (Maciak and Liwski 1996). The values of selected physical properties (bulk density, particle density, porosity, saturated volumetric moisture content and degree of decomposition) for all analysed soil layers were presented by Oleszczuk and Truba (2013).

\section{RESULTS AND DISCUSSION}

The research presented in this paper included measurements of the following chemical properties: organic carbon, total nitrogen, $\mathrm{C}: \mathrm{N}$ ratio, ash content and $\mathrm{pH}$.

Organic carbon content is quite low for alder peat (23-34\%) and quite high for the rest analysed soil samples including also moorsh layers. The lowest values of $\mathrm{C}$ are observed in top layers, where the 
degree of decomposition is the largest (Table 2).

Total nitrogen values obtained during the test was in the range $1.8-3.0 \%$ (Table 2). According to Gotkiewicz (2007), these results are typical for fenpeat, the accumulation and the high values of nitrogen as a result of nitrification and denitrification processes as a result of drying process. Similar results were obtained by Niedermeier and Robinson (2007) for drained fen-peats in the United Kingdom (1.7-3.2\%), by Pawluczuk and Gotkiewicz (2003) for drained fen-peats in north-eastern Poland (1.96-3.05\%). In contrast to organic carbon content the total nitrogen values are higher in top soil layers as reason of accumulation of this compounds due to high mineralization processes. In Europe, depending on the depth of the layer, total nitrogen content ranges from $0.41 \%$ for the raised bogs in Latvia (Klavins et al. 2008) to $3.78 \%$ for the fen-peats in Poland (Sokołowska et al. 2011; Boguta and Sokołowska 2012).

The relationship C:N describes the ratio of decomposition of organic matter. The wide range of this parameters were observed for Powsin $(45-55 \mathrm{~cm})$, Lamane Grądy and Brzostówka (45$-55 \mathrm{~cm}$ ) sites (quite low degree of decomposition) and the lowest values of this parameter for Solec $(10-20 \mathrm{~cm})$ and Bełda sites (Table 2). The lower $\mathrm{C}: \mathrm{N}$ ratio shown

TABLE 2. Characteristics of some chemical properties of analysed peat-moorsh soil layers

\begin{tabular}{|c|c|c|c|c|c|c|c|c|}
\hline $\begin{array}{l}\text { No } \\
\text { of } \\
\text { site }\end{array}$ & $\begin{array}{l}\text { Name of } \\
\text { site }\end{array}$ & $\begin{array}{c}\text { Depth of } \\
\text { sampling } \\
{[\mathrm{cm}]}\end{array}$ & $\begin{array}{c}\text { Organic } \\
\text { carbon } \\
(\mathrm{C}) \\
{[\%]}\end{array}$ & $\begin{array}{c}\text { Total } \\
\text { nitrogen } \\
(\mathrm{N}) \\
{[\%]}\end{array}$ & $\begin{array}{c}\mathrm{C}: \mathrm{N} \\
\text { ratio } \\
{[-]}\end{array}$ & $\begin{array}{c}\text { Ash content } \\
{[\%]}\end{array}$ & $\begin{array}{c}\mathrm{pH} \\
\text { (in } \mathrm{H}_{2} \mathrm{O} \text { ) } \\
{[-]}\end{array}$ & $\begin{array}{l}\text { Peat } \\
\text { group }\end{array}$ \\
\hline 1 & Bełda & $30-40$ & 23.63 & 1.80 & 13.1 & 43.48 & 5.65 & \multirow{2}{*}{ Alder } \\
\hline 2 & Solec & $35-45$ & 34.20 & 2.46 & 13.9 & 24.03 & 5.14 & \\
\hline 3 & Miecze & $50-60$ & 39.20 & 2.67 & 14.7 & 13.19 & 5.55 & \multirow{3}{*}{ Reed } \\
\hline 4 & Sołki & $50-60$ & 41.98 & 2.42 & 17.3 & 10.95 & 5.16 & \\
\hline 5 & $\begin{array}{l}\text { Dąbrówka } \\
\text { Stany } 1\end{array}$ & $60-70$ & 37.08 & 2.52 & 14.7 & 19.35 & 5.54 & \\
\hline 6 & Powsin & $30-45$ & 34.07 & 2.27 & 15.0 & 26.65 & 5.11 & \multirow{5}{*}{ Sedge } \\
\hline 7 & Powsin & $45-55$ & 34.07 & 2.14 & 19.1 & 16.01 & 5.11 & \\
\hline 8 & Brzostówka & $45-55$ & 46.55 & 2.58 & 18.0 & 11.58 & 5.17 & \\
\hline 9 & $\begin{array}{l}\text { Dąbrówka } \\
\text { Stany } 2\end{array}$ & $45-55$ & 40.33 & 2.40 & 16.8 & 19.69 & 5.36 & \\
\hline 10 & $\begin{array}{c}\text { Dąbrówka } \\
\text { Stany } 1\end{array}$ & $45-55$ & 35.25 & 2.44 & 14.4 & 18.85 & 5.50 & \\
\hline 11 & Lamane Grądy & $50-60$ & 36.73 & 2.03 & 18.1 & 22.60 & 5.19 & Moss \\
\hline 12 & Brzostówka & $15-25$ & 39.88 & 2.96 & 13.5 & 12.26 & 5.19 & \multirow{3}{*}{ Moorsh } \\
\hline 13 & $\begin{array}{c}\text { Dąbrówka } \\
\text { Stany } 2\end{array}$ & $20-30$ & 40.67 & 2.55 & 15.9 & 22.05 & 5.32 & \\
\hline 14 & Solec & $10-20$ & 28.34 & 2.33 & 12.2 & 34.08 & 4.93 & \\
\hline
\end{tabular}


high degree of mineralization of organic matter in the peatland (Mazurek and Nicia 2006). Narrow range of $\mathrm{C}: \mathrm{N}$ was obtained in studies by Kechavarzi et al. (2010) in United Kingdom which amounted to 14.2. Wide range of $\mathrm{C}: \mathrm{N}$ were established for peatlands in France with the result of 54.2 (Naasz et al. 2008).

The type of lowland fen peat and the genesis of the peat cause the differences in ash content. No silted organic soils not exceeded $25 \%$ of ash content (Okruszko 1994). The lowest values of ash content are observed for reed peat $(10.5 \%)$, sedge peat $(11.7 \%)$ and the higher values for alder and moss peats (14-14.4\%) (Ilnicki 2002, Rydelek 2011).

According to Maciak and Liwski (1996), fen-peat contain from 8 to $20 \%$ of the dry matter content of ash, for example objects: Sołki, Brzostówka, Miecze, Dąbrówka Stany 1 and Dąbrówka Stany 2. The other objects significantly exceeded $20 \%$ of the dry matter content, what is the effect of alluvial deposit of mineral parts coming with water from the upper sites. Typical results for the lowland fenpeats in Poland received Kamiński (2008) $13.5-25.7 \%$ d.m. and Oleszczuk et al. (2009) 11.96-12.28\% d.m., Boguta with Sokołowska (2012) $17.6-22.7 \%$ d.m. Very low content of mineral part obtained Gondar et al. (2005) 2.6-4.5\% d.m. for peatland in Spain and Klavins et al. (2008) $4.96-6.15 \%$ for peatland in Latvia.

The $\mathrm{pH}$ of peat on the studied objects ranged from 4.93 to 5.65 , these were the characteristic values for fen-peat or eventually for transition peat (Maciak and Liwski 1996). All peatlands except object Solec $(10-20 \mathrm{~cm})$ were classified as medium acidic peat. Object Solec (10 $-20 \mathrm{~cm}$ ) was strongly acidic (Table 2).

Table 3 shows a comparison of all investigated physical and chemical properties of peat soils. Grey color in the Table 3 represents the linear correlation above $0.6\left(R^{2}\right)$.

TABLE 3. The values of the linear correlation between the considered physical and chemical properties of the analysed objects; $\rho_{\mathrm{p}}$-particle density, $\rho_{\mathrm{b}}$ - bulk dencity, $\Theta_{\text {sat }}-$ saturated volumetric moisture content, $\mathrm{C}_{\text {org }}-$ organic carbon, $\mathrm{N}_{\mathrm{og}}-$ total nitrogen, $\mathrm{n}=56$, critical value $=0.263$

\begin{tabular}{|l|c|r|r|r|c|}
\hline $\begin{array}{l}\text { Physical and cheminal } \\
\text { properties }\end{array}$ & $\begin{array}{c}\mathrm{C}_{\text {org }} \\
{[\%]}\end{array}$ & $\begin{array}{c}\mathrm{N}_{\mathrm{og}} \\
{[\%]}\end{array}$ & $\begin{array}{c}\text { C:N } \\
\text { ratio } \\
{[-]}\end{array}$ & $\begin{array}{c}\text { Ash content } \\
{[\%]}\end{array}$ & $\begin{array}{c}\mathrm{pH} \\
\left.\text { (in } \mathrm{H}_{2} \mathrm{O}\right)\end{array}$ \\
\hline$\rho_{\mathrm{b}}\left[\mathrm{Mg} \cdot \mathrm{m}^{-3}\right]$ & -0.945 & -0.587 & -0.873 & 0.829 & -0.515 \\
\hline$\rho_{\mathrm{p}}\left[\mathrm{Mg} \cdot \mathrm{m}^{-3}\right]$ & -0.829 & -0.822 & -0.700 & 0.954 & 0.375 \\
\hline Porosity [\%] & 0.913 & 0.438 & 0.888 & -0.769 & 0.324 \\
\hline$\Theta_{\text {sat }}[$ vol. \%] & 0.730 & 0.482 & 0.884 & -0.748 & 0.473 \\
\hline Degree of decomposition [\%] & -0.656 & 0.212 & -0.762 & 0.612 & 0.338 \\
\hline $\mathrm{C}_{\text {org }}[\%]$ & & 0.760 & 0.843 & -0.881 & -0.409 \\
\hline $\mathrm{N}_{\mathrm{og}}[\%]$ & & & -0.394 & -0.691 & -0.324 \\
\hline C:N ratio [-] & & & & -0.719 & -0.375 \\
\hline $\begin{array}{l}\text { Ash content (in dry matter } \\
- \text { d.m.) }[\%]\end{array}$ & & & & 0.324 \\
\hline
\end{tabular}


Based on data presented in Table 3 it can be concluded, that the strong relationship are between some physical properties (bulk density, particle density, porosity, saturated moisture content) and some chemical properties (organic carbon content, $\mathrm{C}: \mathrm{N}$ ratio, ash content). Among chemical properties the relationships between organic content with $\mathrm{C}: \mathrm{N}$ ratio and ash content are observed. Degree of decomposition and $\mathrm{pH}$ are the parameters which shown very weakly correlation with other analyzed physical and chemical properties.

The relationships between ash content and organic carbon, total nitrogen, bulk density, and particle density are presented on Figure 1. The all analyzed relationships shown linear regressions. Increasing of ash content causes the decreasing of organic carbon as well as total nitrogen (Fig. 1a-b). Increasing of ash content causes also increasing of physical parameters: bulk and particle densities (Fig. 1c-d). Specially the strong relationship between ash content and particle density is observed $\left(\mathrm{R}^{2}=0.911\right)$.

The obtained in this work relationship between particle density and ash content were compared with the data published in the literature (Fig. 2).

The equation presented by Okruszko (1971) shows higher values of particle density of about $0.08-0.1 \mathrm{Mg} \cdot \mathrm{m}^{-3}$ in the ash content range from 20 to $40 \%$ in

b)

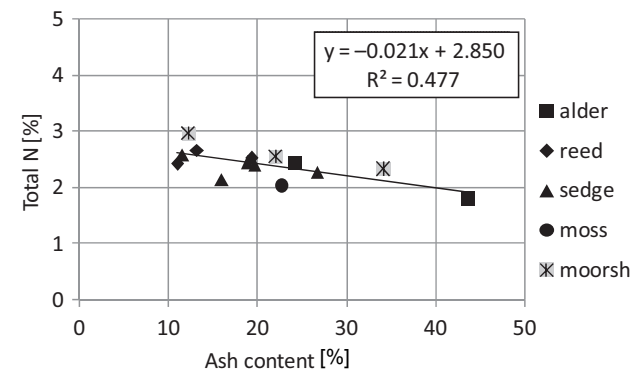

d)

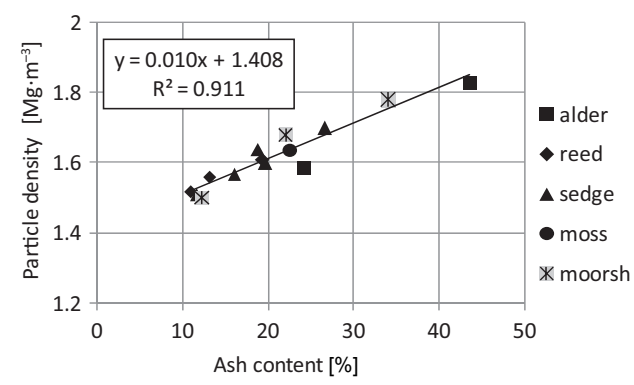

FIGURE 1. The relationship between ash content and organic carbon (a), total nitrogen (b), bulk density (c) and particle density (d) 


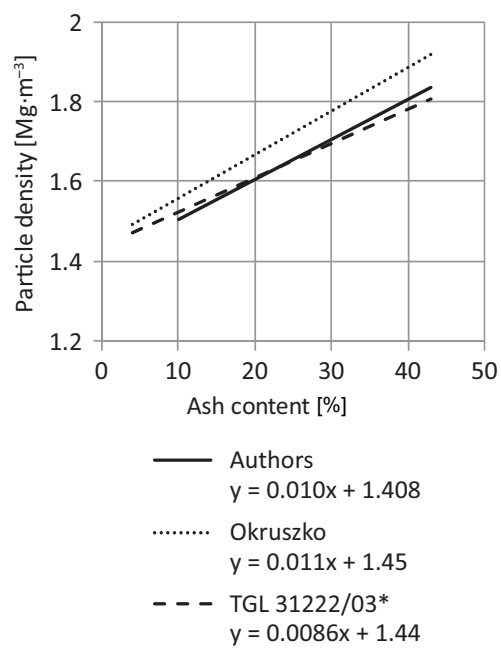

* Standard methods in soil physics - density and porosity in German (TGL 31222/03, 1985).

FIGURE 2. The comparison of relationships between particle density and ash content

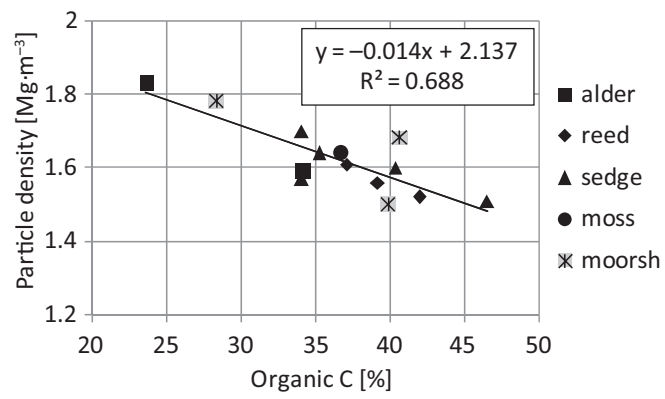

FIGURE 4. The characteristic of particle density and organic carbon for analysed soil layers

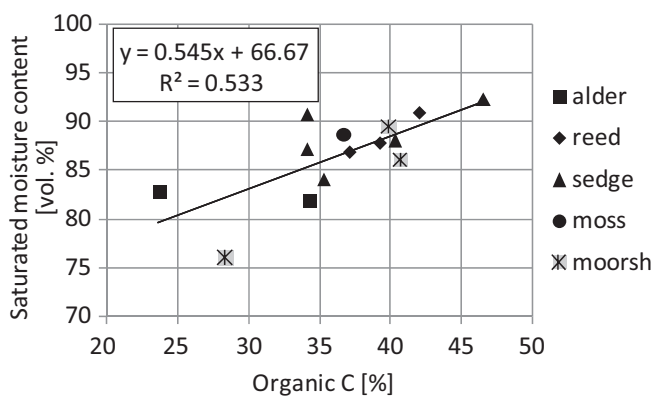

FIGURE 5. The relationship between saturated moisture content and organic content for considered soil layers

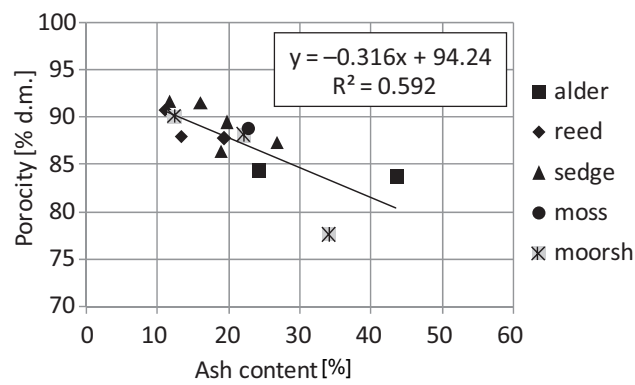

FIGURE 3. The comparison between porosity and ash content for considered soil layers

comparison with equation proposed in this work. The proposed in this paper relationship is very similar to the equation proposed for German peat soils.

The decrease of ash content causes the increasing of porosity values of analysed soil samples (Fig. 3).

Increasing of organic carbon content causes decreasing of particle density values (Fig. 4) and increasing of saturated moisture content (Fig. 5).

\section{CONCLUSIONS}

Based on performed research the following conclusions can be proposed:

1) The drainaged peat-moorsh soil layers shown the decreasing of organic carbon content and increasing of total nitrogen specially in the upper layers.

2) The relatively low values ofC:Nratio shown for some peat and moorsh layers with the medium and high stage of degradation due to former drainage process $(1: 12 \div 1: 13)$.

3) The performed research shown strong relationship between some chemical and physical properties. 
For example strong linear relationship are observed between organic carbon content and bulk density, particle density, and porosity in analysed soil samples.

4) Increasing of ash content in analysed soil samples (from 10 to $40 \%$ d.m.) caused decreasing of organic carbon content (from around 42 to $24 \%$ ), total nitrogen (from 3 to $2 \%$ ) and porosity values (from 90 to $80 \%$ ) respectively.

5) Increasing of ash content in analysed soil samples (from 10 to $40 \%$ d.m.) caused increasing of physical parameters, like bulk density (from 0.1 to $0.35 \mathrm{Mg} \cdot \mathrm{m}^{-3}$ ) and particle density values (from around 1.5 to $1.8 \mathrm{Mg} \cdot \mathrm{m}^{-3}$ ) respectively.

6) Established in this work the relationship between particle density and ash content is very similar with the same equation established for German peat soils. The proposed in this work equation gives some lower values of particle density calculated using ash content in comparison with formula proposed by Okruszko (1971).

\section{REFERENCES}

BOGUTA P., SOKOŁOWSKA Z. 2012: Influence of phosphate ions on buffer capacity of soil humic acids. Int. Agrophys. 26: 7-14.

BRANDYK A. 2011: Ground water fed system restoration on the area of Przemkowsko-Przecławskie Wetlands. Ann. Warsaw Univ. of Life Sci. - SGGW, Land Reclam. 43(1): $13-23$.

BRANDYK T., SZATYŁOWICZ J., OLESZCZUK R., GNATOWSKI T. 2003: Water-related physical attributes of organic soils. In: Organic soils and peat materials for sustainable agriculture. L.-E. Parent, P. Ilnicki (Eds.). CRC Press and International Peat Society, Boca Raton, Florida (USA): 33-66.
CLARK J.M., VAN DER HEIJDEN G.M.F., PALMER S.M., CHAPMAN P.J., BOTTRELL S.H. 2011: Variation in the sensitivity of DOC release between different organic soils following $\mathrm{H}_{2} \mathrm{SO}_{4}$ and sea-salt additions. European Journal of Soil Science 62: 267-284.

GEBHART S., FLEIGE H., HORN R. 2009: Shrinkage processes of a drained riparian peatland with subsidence morphology. J. of Soil Sediments. DOI 10.1007/s11368-009-0130-9.

GNATOWSKI T. 2009: Analysis of thermal diffusivity data determined for selected organic topsoil layer. Ann. Warsaw Univ. of Life Sci. - SGGW, Land Reclam. 41(2): 95-107.

GNATOWSKI T., SZATYŁOWICZ J., BRANDYK T. 2002: Effect of decomposition on the capillary rise in peat-moorsh soils from Biebrza River Valley. Int. Agrophysics 16: 97-102.

GNATOWSKI T., SZATYŁOWICZ J., BRANDYK T., KECHAVARZI C. 2009: Hydraulic properties of fen peat soils in Poland. Geoderma 154: 188-195.

GONDAR D., LOPEZ R., FIOL S., ANTELO J.M., ARCE F. 2005: Characterization and acid-base properties of fulvic and humic acids isolated from two horizons of an ombrotrophic peat bog. Geoderma 126: 367-374.

GOTKIEWICZ J. 2007: Azot i fosfor w glebach hydrogenicznych. [Nitrogen and phosphorous in hydrogenic soils]. In: E. Biernacka (Ed.). Torfowiska i mokradła. Wyd. SGGW, Warszawa: 63-74 [in Polish].

ILNICKI P. 2002: Torfowiska i torf. [Peatlands and peat]. Wyd. AR w Poznaniu: 306 [in Polish].

ILNICKI P., IWASZYNIEC P. 2002: Emission of greenhouse gases (GHG) from peatland. In: P. Ilnicki (Ed.). Restoration of carbon sequestration capacity and biodiversity in abandoned grassland on peatland in Poland. Wydawnictwo AR, Poznań: 19-57.

JURCZUK S. 2011: Melioracyjne uwarunkowania zachowania materii organicznej w użytkowanych łąkowo glebach pobagiennych. [Reclamation determinants of organic matter preservation in post-bog soils under meadows]. Rozpr. i Monogr. Nr 30. Wyd. IMUZ, Falenty [Eng. summ.].

KAMIŃSKI J. 2008: Zróżnicowanie florystyczne i walory przyrodnicze łąk 2-kośnych na zagospodarowanym torfowisku w zależności od warunków wilgotnościowych. [Floristic 
differentiation and natural values of 2-cut meadows on managed peatland in relation to moisture conditions]. Woda - Środowisko - Obszary Wiejskie 8, 2a(23): 87-104 [Eng. summ].

KECHAVARZI C. DAWSON Q., BARTLETT M., LEEDS-HARRISON P.B. 2010: The role of soil moisture, temperature and nutrient amendment on $\mathrm{CO}_{2}$ efflux from agricultural peat soil microcosms. Geoderma 154: 203-210.

KLAVINS M., SIRE J., PURMALIS O., MELECIS V. 2008: Approaches to estimating humification indicators for peat. Mires and Peat 3, article 07.

MACIAK F., LIWSKI S. 1996: Ćwiczenia z torfoznawstwa. [Peatlans quide-book]. Wyd. SGGW, Warszawa.

MAZUREK R., NICIA P. 2006: Charakterystyka glebowo-roślinna obwodu ochronnego Grzędy w Biebrzańskim Parku Narodowym. [Soil-plant characteristics of protection area Grzędy in the Biebrza national Park]. In: T. Brandyk, L. Szajdak, J. Szatyłowicz (Eds). Właściwości fizyczne i chemiczne gleb organicznych. Wyd. SGGW, Warszawa: 215-222 [Eng. summ.].

NAASZ R., MICHEL J.C., CHARPENTIER S. 2008: Water repellency of organic growing media related to hysteretic water retention properties. European Journal of Soil Science 59: 156-165.

NAMIEŚNIK J., JAMRÓGIEWICZ Z., PILARCZYK M., TORRES L. 2000: Preparation of environmental samples for analysis. WN-T, Warszawa [in Polish].

NIEDERMEIER A., ROBINSON J.S. 2007: Hydrological controls on soil redox dynamics in a peat-based, restored wetland. Geoderma 137: 318-326.

OKRUSZKO H. 1971: Określanie ciężaru właściwego gleb hydrogenicznych na podstawie zawartości w nich części mineralnych. [Determination of specific gravity of hydrogenic soils on the basis of their mineral particles content]. Wiad. IMUZ 10, 1: 47-54 [Eng. summ.].

OKRUSZKO H. 1993: Transformation of fen-peat soil under the impact of draining. Zesz. Probl. Post. Nauk Rol. 406: 3-73.

OLESZCZUK R., BOHNE K., SZATYŁOWICZ J., BRANDYK T., GNATOWSKI T. 2003: Influence of load on shrinkage behaviour of peat soils. J. Plant Nutr. Soil Sci. 166: 220-224.
OLESZCZUK R., CHRZANOWSKI S., BRANDYK T., GNATOWSKI T., SZATYŁOWICZ J. 2009: Ocena funkcjonowania systemu odwadniająco-nawadniającego dla zrównoważonego łąkowego wykorzystania gleby torfowo-murszowej. [An assesment of the drainage-subirrigation system for sustainable use of peat-moorsh soil]. Woda - Środowisko - Obszary Wiejskie 9, 1(25): 77-86 [Eng. summ.].

OLESZCZUK R., REGINA K., SZAJDAK L., HÖPER H., MARYGANOVA V. 2008: Impacts of agricultural utiliazation of peat soil son the greenhouse gas balance. In: M. Strack (Ed.). Peatlands and climate change. International Peat Society vapaudenkatu, Jyvaskyla, Finland: 70-97.

OLESZCZUK R., SZATYŁOWICZ J., BRANDYK T., GNATOWSKI T. 2000: An analysis of the influence of shrinkage on water retention characteristcs of fen peat-moorsh soil. Suo 51(3): 139-147.

OLESZCZUK R., TRUBA M. 2013: The analysis of some physical properties of drained peat-moorsh layers. Ann. Warsaw Univ. of Life Sci. - SGGW, Land Reclam. 45(1): 41-48.

PAWLUCZUK J., GOTKIEWICZ J. 2003: Ocena procesu mineralizacji azotu w glebach wybranych ekosystemów torfowiskowych Polski północno-wschodniej w aspekcie ochrony zasobów glebowych. [Evaulation of the nitrogen mineralization process in soils of some peat ecosystems of north-eastern Poland in the aspect of soil resources conservation]. Acta Agrophysica 1(4): 721-728 [Eng. summ.].

PENG X., HORN R. 2007: Anisotropic shrinkage and swelling of some organic and inorganic soils. European Journal of Soil Science 58: 98-107.

QUERNER E.P., JANSEN P.C., van den AKKER J.J.H., KWAKERNAAK C. 2012: Analysing water level strategies to reduce soil subsidence in Dutch peat meadows. J. Hydrology 446-447: 59-69.

RYDELEK P. 2011: Geneza i skład części mineralnych wybranych złóż torfów niskich Wysoczyzny Lubartowskiej. [Origin and composition of mineral particles of selected peat deposits in Lubartowska Upland]. Woda - Środowisko - Obszary Wiejskie 11, 2(34): 135-149 [Eng. summ.].

Roczniki Gleboznawcze [Polish Soil Classification] 2011: tom 62, nr 3 [in Polish]. 
SAPEK A., SAPEK B. 1997: Metody analizy chemicznej gleb organicznych. [Methods of chemical annalysis of organic soils]. Mat. Instr. 115. IMUZ, Falenty [in Polish].

SOKOŁOWSKA Z., SZAJDAK L., BOGUTA P. 2011: Effect of phosphates on dissolved organic matter release from peat-muck soils. Int. Agrophys. 25: 173-180.

Systematyka gleb Polski 2011 [Polish Soil Classification], Roczniki gleboznawcze (J. Marcinek, J. Komisarek - red. nauk.), T. 62, nr 3 [in Polish].

TGL 31222/03 1985: Standard methods in soil physics - Density and porosity in German. Staatlich Technische Normen, Gütevorschriften und Lieferbedingungen Standards der DDR, Berlin.

WÖSTEN J.H.M., ISMAIL A., VAN WIJK A. 1997: Peat subsidence and its practical implications: case study in Malaysia. Geoderma 78: 25-36.

ZAWADZKI S., OLSZTA W. 1989: The changes of physico-water properties of excessively dried hydrogenic soils. Pol. J. Soil Sci. 22(1): 1-9.

ZEITZ J., VELTY S. 2002: Soil properties of drained and rewetted fen soils. J. Plant Nutr. Soil Sci. 165: 618-626.

Streszczenie: Analiza podstawowych właściwości chemicznych i fizycznych odwodnionych warstw torfowych i murszowych. Próby do analiz pobrano z 14 warstw odwodnionych gleb torfowo-murszowych zlokalizowanych w północno-wschodniej, centralnej i wschodniej Polsce znajdujących się $\mathrm{w}$ zasięgu funkcjonujących w przeszłości systemów melioracyjnych. W pracy przedstawiono wyniki badań wybranych właściwości chemicz- nych (węgiel organiczny, azot ogólny, stosunek $\mathrm{C}: \mathrm{N}$, popielność) oraz relacje pomiędzy badanymi właściwościami chemicznymi a wybranymi właściwościami fizycznymi (zależność popielności od gęstości gleby, gęstości fazy stałej, porowatości). Wzrost zawartości popielności z poziomu 10 do $40 \%$ a.s.m. pociagga za sobą zmniejszenie się zawartości węgla organicznego, azotu ogólnego i porowatości, powoduje natomiast wzrost wartości gęstości objętościowej gleby oraz gęstości fazy stałej.

Stowa kluczowe: torf, odwodnienie, humifikacja, mineralizacja, zmiany właściwości chemicznych i fizycznych

\section{MS. received in February 2014}

\section{Authors' addresses:}

Milena Truba

Katedra Łąkarstwa i Kształtowania Terenów Zieleni

Wydział Przyrodniczy

Uniwersytet Przyrodniczo-Humanistyczny

w Siedlcach

ul. Bolesława Prusa 14

08-110 Siedlce

e-mail: milena.truba@gmail.com

Ryszard Oleszczuk

Katedra Kształtowania Środowiska

Wydział Budownictwa i Inżynierii Środowiska SGGW

ul. Nowoursynowska 159

02-776 Warszawa

e-mail: ryszard_oleszczuk@sggw.pl 